University of Nebraska - Lincoln

DigitalCommons@University of Nebraska - Lincoln

U.S. Environmental Protection Agency Papers

U.S. Environmental Protection Agency

2008

\title{
Catfish consumption as a contributor to elevated PCB levels in a non-Hispanic black subpopulation
}

\author{
Max Weintraub \\ US Environmental Protection Agency, Communities and Ecosystems Division, 75 Hawthorne Street \\ (CED-4), San Francisco, CA 94105, USA \\ Linda S. Birnbaum \\ US Environmental Protection Agency, National Health and Environmental Effects Laboratory, Research \\ Triangle Park, NC 27709, USA
}

Follow this and additional works at: https://digitalcommons.unl.edu/usepapapers

Part of the Civil and Environmental Engineering Commons

Weintraub, Max and Birnbaum, Linda S., "Catfish consumption as a contributor to elevated PCB levels in a non-Hispanic black subpopulation" (2008). U.S. Environmental Protection Agency Papers. 23.

https://digitalcommons.unl.edu/usepapapers/23

This Article is brought to you for free and open access by the U.S. Environmental Protection Agency at DigitalCommons@University of Nebraska - Lincoln. It has been accepted for inclusion in U.S. Environmental Protection Agency Papers by an authorized administrator of DigitalCommons@University of Nebraska - Lincoln. 
Review

\title{
Catfish consumption as a contributor to elevated PCB levels in a non-Hispanic black subpopulation
}

\author{
Max Weintraub $^{\mathrm{a}, *}$, Linda S. Birnbaum ${ }^{\mathrm{b}}$ \\ ${ }^{a}$ US Environmental Protection Agency, Communities and Ecosystems Division, 75 Hawthorne Street (CED-4), San Francisco, CA 94105, USA \\ ${ }^{\mathrm{b}}$ US Environmental Protection Agency, National Health and Environmental Effects Laboratory, Research Triangle Park, NC 27709, USA
}

\section{A R T I C L E I N F O}

\section{Article history:}

Received 8 October 2007

Received in revised form

28 February 2008

Accepted 4 March 2008

Available online 14 April 2008

\section{Keywords:}

PCB

Polychlorinated biphenyl

Body burden

Disparity

Catfish

African American

Fish consumption

Fish advisory

Environmental justice

\begin{abstract}
A B S T R A C T
The human body burden of polychlorinated biphenyls (PCBs) sharply declined after production was banned in the US in 1979. For the $10 \%$ of the US population that remains most exposed to PCBs, fish consumption is the primary source. National Health and Nutrition Examination Survey (NHANES) data indicates that the highest remaining PCB levels exist in a non-Hispanic black subpopulation. Our review suggests that catfish consumption may be a significant PCB source for the one million non-Hispanic black anglers who fish for catfish. In comparison to non-Hispanic white anglers, non-Hispanic black anglers consume more catfish, are more likely to eat the whole fish rather than just the fillets that contain less PCBs, and are more likely to fish in watersheds with high PCB contamination.

Efforts to diminish potential racial disparities in PCB exposure are challenged by geographic, economic, cultural, and educational barriers. In response, we propose that a fish consumption survey be performed that identifies the extent of subsistence fishing by non-Hispanic black anglers for catfish in watersheds with PCB contamination, the type and quantity of catfish subsistence fishing provides, and what actions would help moderate PCB exposure due to subsistence fishing for catfish in such areas. Understanding the contamination and consumption factors that contribute to higher PCB body burdens will help identify and offer solutions to racial disparities in exposure to PCBs due to subsistence fishing while providing a model to prevent similar disparities in exposure to toxics ranging from mercury to polybrominated diphenyl ethers.
\end{abstract}

\section{Contents}

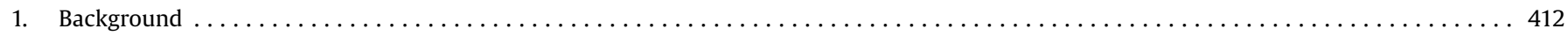

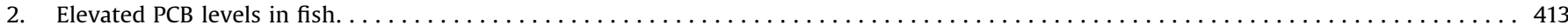

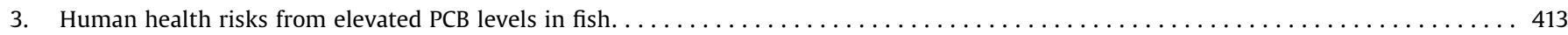

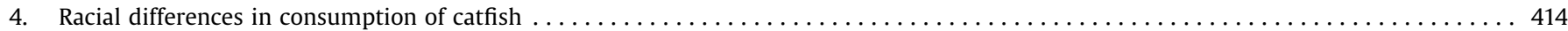

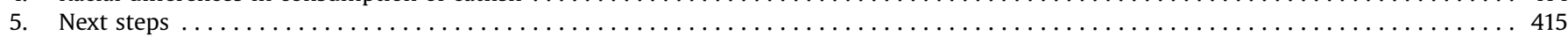

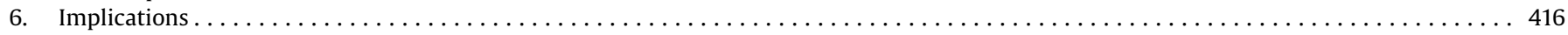

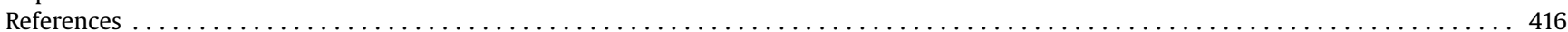

\section{Background}

Polychlorinated biphenyls (PCBs) are a group of anthropogenic compounds that can alter a wide range of human body functions, including immune, reproductive, and neurological systems, and are a probable human carcinogen (Agency for Toxic Substances and Disease Registry (ATSDR), 2000). PCBs consist of two rings

\footnotetext{
* Corresponding author.

E-mail address: weintraub.max@epa.gov (M. Weintraub).
}

of six carbon atoms with a single bond between them and one to ten chlorine atoms at different positions on the rings. Hydrogen atoms fill any of the 10 positions where chlorine atoms are absent. Two hundred and nine different PCB configurations or "congeners" exist.

Between 1929 and 1978 more than 1.2 billion pounds of PCBs were manufactured in the US primarily to use as insulating oil in electrical equipment. Federal regulations that controlled PCB waste disposal in 1978 and banned PCB production in 1979 contributed to a sharp decrease in PCB levels in the US environment during the 1980s (Fensterheim, 1993). Because PCBs 


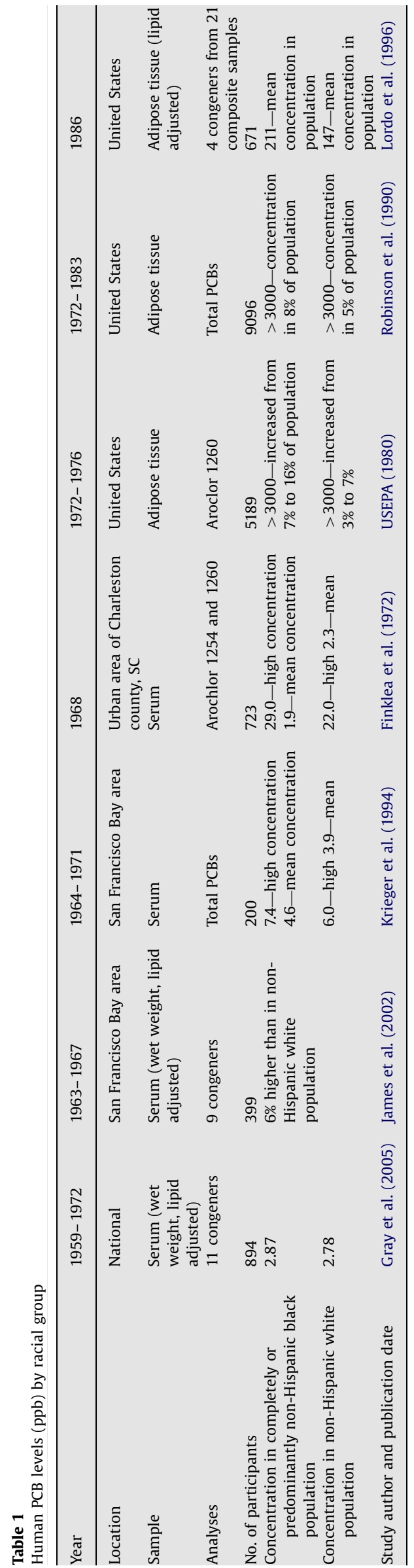

degrade slowly, they bioaccumulate in fatty tissues and biomagnify as they move up the food chain.

The primary source of PCBs for the $10 \%$ of the US population currently most exposed to PCBs are fish high on the food chain consumed from PCB-contaminated lakes, streams, and estuaries (Judd et al., 2004). This represents a significant shift from studies in the 1960s through 1980s that often attributed the highest PCB body burdens in humans to occupational exposure. As summarized in Table 1 and Fig. 1, the higher PCB levels in US populations during that era were found in completely or predominantly nonHispanic black populations (Finklea et al., 1972; James et al., 2002; Krieger et al., 1994; Lordo et al., 1996; Robinson et al., 1990; United States Environmental Protection Agency (USEPA), 1980; Gray et al., 2005; Kutz et al., 1991; National Research Council, 1991). National Health and Nutrition Examination Survey (NHANES) data suggest such racial disparities persist.

PCBs concentrate in fat tissues throughout the body. The most common method for measuring PCBs is in the lipid fraction of blood serum. Although most people in the US have PCBs in fatty tissue, relatively few have levels high enough to be detected in the lipids present in serum. As Table 2 illustrates, the NHANES detected thirteen PCB congeners in serum lipids of at least $5 \%$ of the non-Hispanic black population in the US in 1999-2000 (Centers for Disease Control and Prevention (CDCP), 2003). When compared to the 95th percentile level for the non-Hispanic white population, the concentration for each PCB congener was higher in the non-Hispanic black population. While the disparity diminished, the 2001-2002 NHANES results continued to detect the majority of the PCB congeners examined at the 95th percentile in higher concentrations in the non-Hispanic black population (CDCP, 2005). Given the racial disparity in PCB body burden, and the finding that fish is the primary contributor to high-level PCB exposure, we reviewed how a non-Hispanic black population may be exposed to PCBs from fish consumption.

\section{Elevated PCB levels in fish}

Catfish is the most frequently pursued fish by non-Hispanic black anglers with 50 percent of such anglers pursuing catfish (Henderson, 2004). Since about 6\% of the non-Hispanic black population are anglers, and half of those anglers fish for catfish, approximately 1 million non-Hispanic black anglers fish for catfish. Catfish are the fish most likely contributing to the higher PCB levels in a non-Hispanic black subpopulation.

PCB concentrations averaged between 0.1 and $0.01 \mathrm{ppm}$ in fish tissue composite samples composed primarily of catfish collected in 2000-2003 from lakes and reservoirs nationwide (USEPA, 2005a). However, as Table 3 illustrates, numerous locations exist where catfish with PCB levels $>1 \mathrm{ppm}$ are present (USEPA, 2005b; West Virginia Department of Health and Human Resources, 2006; Wisconsin Department of Natural Resources, 2006; Virginia Department of Environmental Quality (VDEQ), 2003, 2004; United States Fish and Wildlife Service, 2006; Michigan Department of Environmental Quality, 2004; Schlumberger Ltd, 2003; Toaspern, 2003; Delaware River Basin Commission, 2004; Brown et al., 2005; ATSDR, 2005a, b).

\section{Human health risks from elevated PCB levels in fish}

The use of fish tissue data to identify health risks from PCBs started in the early 1970s when federal agencies identified high PCB levels in 58 composite fish tissue samples collected in major US watersheds (Veith et al., 1979). Most samples had a PCB concentration greater than $2 \mathrm{ppm}$. In the third of the samples 


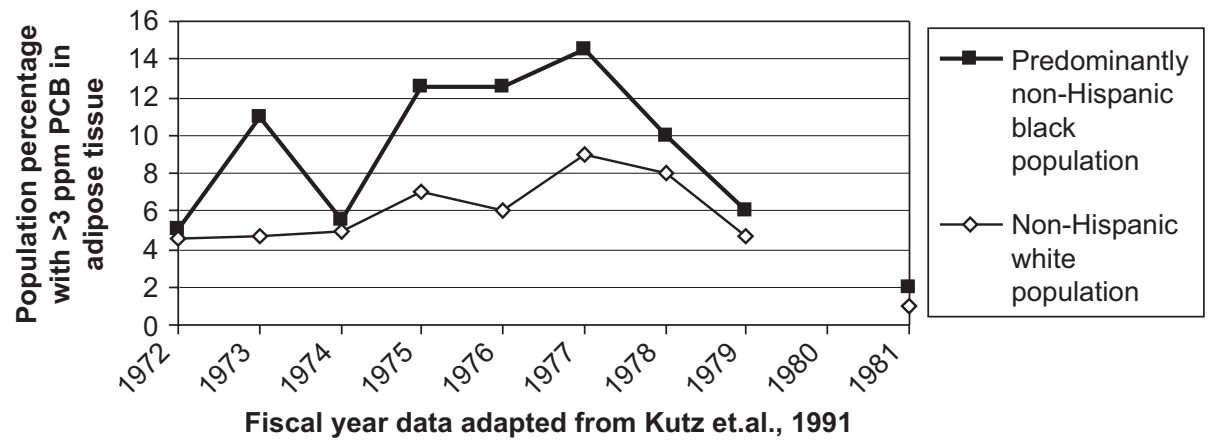

Fig. 1. Historical PCB levels by US racial grouping.

Table 2

Ninety-fifth percentile human serum concentration (lipid adjusted) in ppb (ng/g) for select PCBs in the US by race/ethnicity from 1999-2002

\begin{tabular}{|c|c|c|c|c|}
\hline $\begin{array}{l}\text { PCB } \\
\text { congener }\end{array}$ & $\begin{array}{l}\text { Study } \\
\text { period }\end{array}$ & $\begin{array}{l}\text { Non-Hispanic } \\
\text { black } \\
\text { population }\end{array}$ & $\begin{array}{l}\text { Non-Hispanic } \\
\text { white } \\
\text { population }\end{array}$ & $\begin{array}{l}\text { Toxicity } \\
\text { relative to } \\
\text { TCDD }\end{array}$ \\
\hline \multirow[t]{2}{*}{ РСВ 74} & 1999-2000 & 45.3 & 29.0 & \multirow[t]{2}{*}{$\mathrm{N} / \mathrm{A}$} \\
\hline & $2001-2002$ & 31.5 & 35.5 & \\
\hline \multirow[t]{2}{*}{ РСВ 99} & $1999-2000$ & 31.5 & 18.1 & \multirow[t]{2}{*}{$\mathrm{N} / \mathrm{A}$} \\
\hline & $2001-2002$ & 28.8 & 28.5 & \\
\hline \multirow[t]{2}{*}{ РCB 105} & $1999-2000$ & 12.8 & $<$ LOD & \multirow[t]{2}{*}{0.00003} \\
\hline & $2001-2002$ & $<$ LOD & $<$ LOD & \\
\hline \multirow[t]{2}{*}{ РCB 118} & $1999-2000$ & 59.7 & 40.3 & \multirow[t]{2}{*}{0.00003} \\
\hline & $2001-2002$ & 54.9 & 45.3 & \\
\hline \multirow[t]{2}{*}{ РCВ 126} & $1999-2000$ & 0.120 & 0.0678 & \multirow[t]{2}{*}{0.1} \\
\hline & $2001-2002$ & 0.115 & 0.114 & \\
\hline \multirow{2}{*}{ РCВ 138} & $1999-2000$ & 122 & 70.1 & \multirow[t]{2}{*}{$\mathrm{N} / \mathrm{A}$} \\
\hline & $2001-2002$ & 122 & 96.1 & \\
\hline \multirow[t]{2}{*}{ РCB 146} & $1999-2000$ & 28.1 & $<$ LOD & \multirow[t]{2}{*}{$\mathrm{N} / \mathrm{A}$} \\
\hline & $2001-2002$ & 23.8 & 15.2 & \\
\hline \multirow[t]{2}{*}{ РCВ 153} & $1999-2000$ & 176 & 102 & \multirow[t]{2}{*}{ N/A } \\
\hline & $2001-2002$ & 170 & 126 & \\
\hline \multirow[t]{2}{*}{ РСВ 156} & $1999-2000$ & 21.6 & 17.4 & \multirow[t]{2}{*}{0.00003} \\
\hline & $2001-2002$ & 23.5 & 19.3 & \\
\hline \multirow[t]{2}{*}{ РСВ 169} & $1999-2000$ & 0.0511 & 0.0453 & \multirow[t]{2}{*}{0.03} \\
\hline & $2001-2002$ & 0.0548 & 0.0643 & \\
\hline \multirow[t]{2}{*}{ РСВ 170} & $1999-2000$ & 39.6 & 31.0 & \multirow[t]{2}{*}{$\mathrm{N} / \mathrm{A}$} \\
\hline & $2001-2002$ & 44.1 & 35.0 & \\
\hline \multirow[t]{2}{*}{ РСВ 180} & $1999-2000$ & 117 & 79.0 & \multirow[t]{2}{*}{$\mathrm{N} / \mathrm{A}$} \\
\hline & $2001-2002$ & 116 & 87.9 & \\
\hline \multirow[t]{2}{*}{ РСВ 187} & $1999-2000$ & 47.1 & 22.0 & \multirow[t]{2}{*}{$\mathrm{N} / \mathrm{A}$} \\
\hline & $2001-2002$ & 43.5 & 27.4 & \\
\hline
\end{tabular}

Adapted from CDCP, 2003; CDCP, 2005 and Van den Berg et al., 2006.

$<$ LOD — below level of detection, N/A—not available.

where catfish constituted at least half of the fish tissue tested, the PCB concentrations tended to be greater and included one sample from Lake Hartwell, SC with a PCB concentration of $140 \mathrm{ppm}$.

Shortly thereafter, the Food and Drug Administration (FDA) established a $2 \mathrm{ppm}$ tolerance level for PCBs in fish on the basis that such a level posed minimal cancer risk to the typical market shopper. The FDA also concluded that providing similar protection to subsistence anglers was prohibitively expensive and beyond FDA jurisdiction (Institute of Medicine, 1991).

Most states currently issue fish advisories for PCBs based upon the FDA $2 \mathrm{ppm}$ tolerance level. PCBs have triggered more advisories to halt or limit fish consumption in the US than any substance other than mercury and include fish found in more than 7200 sq miles of lakes and 110,000 miles of rivers (USEPA, 2005c). Our review of current fish advisories for PCBs nationwide found that 25 states have issued 75 "Do Not Consume" advisories for catfish to the general public and an additional 45 "Do Not Consume" advisories for all fish in areas where catfish are present
(USEPA, 2006a). States have also issued more than 200 additional fish advisories for PCBs to limit consumption of catfish by women of childbearing age and children.

States are beginning to refine the risk basis for issuing fish advisories using USEPA standards that consider subsistence anglers. USEPA established a PCB concentration of $0.097 \mathrm{ppm}$ as the threshold for unlimited fish consumption (USEPA, 1999a). Between $10 \%$ and $25 \%$ of a bottom-feeding fish sample composed primarily of catfish, in a 2000-2003 national study of chemical residues in lake fish, had a PCB concentration that exceeded the USEPA threshold (USEPA, 2006c, 2002b).

EPA also incorporated the risk from consumption of such catfish into water quality criteria. The PCB water quality criteria established by the USEPA is $64 \mathrm{pg} / \mathrm{L}$ (USEPA, 2002a). The cancer risk from consuming fish from watersheds that meet the $\mathrm{PCB}$ water quality criteria is one in a million. Thus, the risk that a person consuming fish from watersheds that exceed the $\mathrm{PCB}$ water quality criteria by 10 -fold will develop cancer is one out of 100,000. A 2003 EPA study of 150 watersheds in 12 states (out of 2100 watersheds nationwide) identified 20 watersheds that exceed the water quality criteria for PCBs by 10 -fold (USEPA, 2003).

The non-Hispanic black population in the US exceeds the national average (i.e., 13\%) in only a fifth of the 3000 US counties. A random distribution suggests that only four of the 20 watersheds should have a non-Hispanic black population greater than the national average. Instead, our demographic review of the 2003 EPA study found, as Table 4 illustrates, that 10 of the 20 watersheds that exceed the PCB water quality criteria by 10 -fold had a non-Hispanic black population exceeding thirteen percent (USEPA, 2006b).

In the case of the Middle Chattahoochee watershed straddling the border of Alabama and Georgia, the non-Hispanic black population approaches 50\%. The Middle Coosa watershed located nearby was not included in the USEPA study, but also has a nonHispanic black population in excess of $25 \%$ of the total population and very high PCB levels in catfish. The watershed includes the Choccolocco Creek and Lake Logan Martin, where the 2003 reported PCB levels in catfish were up to 49 and $58 \mathrm{ppm}$, respectively (Lorentz, 2005).

\section{Racial differences in consumption of catfish}

Community demographics of watersheds that substantially exceed water quality criteria for PCBs are only one geographic measure of potential disparities in PCB exposure. Ninety percent of non-Hispanic black anglers fish in the Midwest, Northeast, and South regions of the US (Henderson, 2004), where more than three-quarters of fish advisories for PCBs have been issued (USEPA, 1999b). Within those regions, the non-Hispanic black 
Table 3

Catfish tissue levels from 2000-2004

\begin{tabular}{|c|c|c|c|c|c|}
\hline Catfish & Waterbody & State & Date & Maximum PCB (ppm) & Study author and publication date \\
\hline Blue catfish & James river & VA & 2003 & 1.7 & VDEQ (2003) \\
\hline Blue catfish & James river & VA & 2003 & 3.0 & VDEQ (2003) \\
\hline Brown bullhead & Brier creek reservoir & NC & 2003 & 1.7 & $\operatorname{ATSDR}(2005 a, b)$ \\
\hline Brown bullhead & Portland harbor & OR & 2003 & 1.9 & $\operatorname{ATSDR}(2005 a, b)$ \\
\hline Channel catfish & Tittabawassee river & MI & 2003 & 1.1 & MDEQ (2004) \\
\hline Channel catfish & Delaware river & $\mathrm{NJ}-\mathrm{DE}$ & 2001 & 2.4 & DRBC (2004) \\
\hline Channel catfish & Delaware river & NJ-DE & 2001 & 1.9 & Toaspern (2003) \\
\hline Channel catfish & Ashtabula river & $\mathrm{OH}$ & 2002 & 1.4 & USFWS (2006) \\
\hline Channel catfish & Delaware estuary & $\mathrm{NJ}$ & 2002 & 2.1 & DRBC (2004) \\
\hline Channel catfish & Lake Hartwell & SC & 2003 & 2.1 & Schlumberger Ltd. (2003) \\
\hline Channel catfish & Knox creek & VA & 2004 & 2.6 & VDEQ (2004) \\
\hline Channel catfish & Fox river & WI & 2004 & $>1.9$ & WDNR (2006) \\
\hline Channel catfish & Monongahela river & WV & 2002 & 1.9 & WVDHHR (2006) \\
\hline Channel catfish & Ohio river & WV & 2004 & 2.7 & WVDHHR (2006) \\
\hline Flathead catfish & Ohio river & WV & 2000 & 1.6 & WVDHHR (2006) \\
\hline Flathead catfish & Roanoke river & VA & 2004 & 1.6 & VDEQ (2004) \\
\hline Flathead catfish & Lower Schuykill river & PA & 2004 & 1.0 & Brown et al. (2005) \\
\hline
\end{tabular}

Table 4

Watersheds that exceed PCB water quality criteria by 10 -fold and a non-Hispanic black population that exceeds the national percentage

\begin{tabular}{|c|c|c|c|}
\hline Watershed name & $\begin{array}{l}\text { USGS } \\
\text { number }\end{array}$ & $\begin{array}{l}\text { Non-Hispanic black } \\
\text { population (\%) }\end{array}$ & Location \\
\hline $\begin{array}{l}\text { Middle Chattahoochee/ } \\
\text { Walter F. George Rese }\end{array}$ & 03130003 & $>45$ & $\begin{array}{l}\text { Columbus, } \\
\text { GA }\end{array}$ \\
\hline $\begin{array}{l}\text { Middle Chattahoochee/ } \\
\text { Lake Harding }\end{array}$ & 03130002 & $>35$ & $\begin{array}{l}\text { La Grange, } \\
\text { GA }\end{array}$ \\
\hline Detroit & 04090004 & $>25$ & Detroit, MI \\
\hline Lower Ogeechee & 03060202 & $>25$ & Brooklet, GA \\
\hline Lake Michigan & 04060200 & $>20$ & $\begin{array}{l}\text { Lake } \\
\text { Michigan }\end{array}$ \\
\hline Lake St. Clair & 04090002 & $>20$ & $\begin{array}{l}\text { St. Clair } \\
\text { Shores, MI }\end{array}$ \\
\hline Brandywine-Christina & 02040205 & $>15$ & $\begin{array}{l}\text { Wilmington, } \\
\text { DE }\end{array}$ \\
\hline Cohansey-Maurice & 02040206 & $>15$ & $\begin{array}{l}\text { Bridgeton, } \\
\text { PA }\end{array}$ \\
\hline Delaware Bay & 02040204 & $>15$ & $\begin{array}{l}\text { Delaware } \\
\text { Bay }\end{array}$ \\
\hline Lake Erie & 04120200 & $>15$ & Lake Erie \\
\hline
\end{tabular}

population and PCB contamination are concentrated in urban areas.

Economic status also likely contributes to disparities in PCB exposure. The rate of poverty remains elevated in the nonHispanic black population and supports the persistence of subsistence fishing (DeNavas-Walt et al., 2006; Brown and Toth, 2001). Non-Hispanic black anglers spend less money than nonHispanic white anglers and are more likely to fish from shore for catfish than from boats for other fish (Recreational boating and fishing foundation (RBBF), 2002; Henderson, 2004).

There is a cultural component to such practices. During slavery, fishing for nocturnal catfish enabled non-Hispanic black anglers to supplement diets, develop knowledge of rivers along the Underground Railroad, and, in some cases, earn money (Cecelski, 2001). Jim Crow legislation limiting economic opportunity and access to arable land perpetuated subsistence fishing. That legacy may help explain why the rate of fishing among non-Hispanic black anglers is consistent regardless of income (RBBF, 2002; Henderson, 2004; Toth and Brown, 1997). Hundreds of soul food festivals nationwide each year recognize that history and promote catfish consumption.
To be effective, fish advisories must overcome these demographic, geographic, economic, and cultural forces to eliminate potentially high $\mathrm{PCB}$ exposure in the non-Hispanic black subsistence angler population. Fish advisories may not be meeting the challenge. It is unlikely subsistence anglers seek fish advisory information from a website upon which a state relies to disseminate advisories (Webber, 2006). Advisories may not respond to angler needs or, as a river flows through various jurisdictions, present different recommendations despite constant contamination (Campbell et al., 2002; Beehler et al., 2001; Burger, 2004; McDermott et al., 2003; Knuth et al., 2003; Chess et al., 2005). Such confusing and inaccessible guidance helps to explain why the non-Hispanic black population in the Northeast US and urban areas are more likely to be restrained from fishing due to general water pollution concerns rather than specific fish advisories (Burger and Waishwell, 2001).

The limited effectiveness of fish advisories is also evident from persistent racial disparities in fish consumption. Non-Hispanic black anglers are often found to consume 50\% to 100\% more fish than non-Hispanic white anglers (California Environmental Protection Agency, 2001; USEPA, 1997; Toxicology Excellence for Risk Assessment, 1999; Gibson and McClafferty, 2005). Several studies in Pennsylvania and South Carolina have found that nonHispanic black anglers have fish consumption rates that are more than four times greater than non-Hispanic white anglers (National Environmental Justice Advisory Council, 2002; Pennsylvania Coastal Zone Management Program, 2004; Burger, 2002).

The resulting PCB exposure from such consumption is likely disproportionately high as non-Hispanic black anglers are also less likely to trim off the fat, and are more likely to eat whole fish, than non-Hispanic white anglers (Burger et al., 1999). Whole fish can have a five- to 10 -fold greater concentration of PCBs than fillets. Leaving on the skin may allow twice the quantity of PCBs to remain than would be present if the skin (and associated layer of fat beneath) were removed (Strauss, 2004).

\section{Next steps}

The relationship between rates of catfish consumption and the body burden of PCBs among the non-Hispanic black population at the 95th percentile requires further examination. A comprehensive fish consumption survey should target areas meeting the following three criteria: (1) watersheds with fish 
tissue concentrations exceeding health-based national water quality criteria for PCBs by more than 10-fold; (2) areas with general population "Do Not Consume" advisories for catfish; and (3) areas that exceed the percentage of the non-Hispanic black population found nationwide.

The survey should identify the extent of subsistence fishing for catfish, the type and quantity of catfish subsistence fishing provides, and what actions would help moderate or replace subsistence fishing for catfish in areas with high levels of PCB contamination. Data collected should include sources of catfish, frequency of catfish consumption, quantity of catfish consumed, factors encouraging catfish consumption, barriers to alternate sources of catfish, and alternatives to catfish consumption. The analysis of the survey results should model the potential PCB exposure resulting from subsistence fishing for catfish.

\section{Implications}

Additional exposure to PCBs from farmed catfish may also be a concern. Catfish farming is the largest aquaculture industry in the United States (Harvey, 2005). A survey of 3600 farmed catfish consumers found farmed catfish are consumed by $60 \%$ of the non-Hispanic black population and $45 \%$ of the non-Hispanic white population (Engle, 1998). If another survey of 1400 farmed catfish consumers is correct in its findings that up to a quarter of farmed catfish consumers are catfish anglers (House et al., 2003), then it is likely that most catfish anglers also eat farmed catfish.

FDA measurements of the toxicity of farmed catfish fillets have not included dioxin-like PCBs. Farmed salmon studies suggest such examination is warranted. Total dioxin toxic equivalent (TEQ) (Van den Berg et al., 2006) levels up to 2.8 ppt have been found in farmed salmon, have triggered recommendations to limit consumption, and are due primarily to the presence of dioxin-like PCBs (Foran et al., 2005). FDA studies of dioxins and furans (i.e., absent analysis for dioxin-like PCBs) in 2003-2004 found higher TEQ in farmed catfish than farmed salmon (FDA, 2005). TEQ levels in farmed catfish due to dioxins and furans have also been found to exceed $>2.0 \mathrm{ppt}$ as a result of dioxin contamination of fish feed (Hayward et al., 1999) or use of exposure modeling which included the TEQ contribution of dioxins that may be present at low levels (Jensen and Bolger, 2001). Examining the impact of dioxin-like PCBs on TEQ of farmed catfish would complement the dioxin and furan studies and enable a more complete evaluation of consumption risks.

If high-end consumers of catfish in the non-Hispanic black population are exposed to elevated levels of PCBs, any harmful effects will be exacerbated by increased rates of poverty and residential segregation, decreased rates of high-quality food access and healthcare, and other racial stressors (Gee and Payne-Sturges, 2004; House and Williams, 2000). Minimizing exposure to PCBs may diminish such impacts and also provide lessons to prevent disparities in exposure to toxics ranging from mercury to polybrominated diphenyl ethers (PBDEs) through subsistence fishing (USEPA, 2004; Mahaffrey et al., 2004; Hale et al., 2003; Schecter et al., 2004a, b; Schecter et al., 2006; Staskal et al., 2006).

\section{References}

Agency for Toxic Substances and Disease Registry. 2000. Toxicological profile for polychlorinated biphenyls (PCBs). Atlanta, GA: U.S. Department of Health and Human Services, Public Health Service.

Agency for Toxic Substances and Disease Registry. 2005a. Public Health Assessment-Portland Harbor (EPA Facility ID: ORSFN1002155) Portland, Multnomah County, Oregon. Atlanta, GA: ATSDR.
Agency for Toxic Substances and Disease Registry. 2005b. Public Health Assessment-Ward Transformer (EPA Facility ID: NCD003202603), Raleigh, Wake County, North Carolina. Atlanta, GA: ATSDR.

Beehler, G.P., McGuinness, B.M., Bridget, M., Vena, J.E., 2001. Polluted fish, sources of knowledge, and the perception of risk: contextualizing African American anglers' sport fishing practices. Hum. Organ. 60, 288-297.

Brown, J.J., Perillo, J., Kwak, T.J., Horwitz, R.J., 2005. Implications of pylodictis olivaris (flathead catfish) introduction into the delaware and susquehanna drainages. Northeast. Nat. 12 (4), 473-484.

Brown, R.B., Toth Jr, J.F., 2001. Natural resource access and interracial associations: black and white subsistence fishing in the Mississippi Delta. South. Rural Sociol. 17, 81-110.

Burger, J., Stephens, W.L., Boring, C.S., Kuklinski, M., Gibbons, J.W., Gochfeld, M. 1999. Factors in exposure assessment: ethnic and socioeconomic differences in fishing and consumption of fish caught along the Savannah River. Risk Anal. 19, 427-438.

Burger, J., Waishwell, L., 2001. Are we reaching the target audience? Evaluation of a fish fact sheet. Sci. Total Environ. 277, 77-86.

Burger, J., 2002. Daily consumption of wild fish and game: exposures of high end recreationists. Int. J. Environ. Health Res. 12, 343-354.

Burger, J., 2004. Fish consumption advisories: knowledge, compliance and why people fish in an urban estuary. J. Risk Res. 7, 463-479.

California Environmental Protection Agency. 2001. Chemicals in fish: Consumption of fish and shellfish in California and the United States. Final Report. Oakland, CA: Office of Environmental Health Hazard Assessment.

Campbell, K.R., Dickey, R.J., Sexton, R., Burger, J., 2002. Fishing along the clinch river arm of watts bar reservoir adjacent to the oak ridge reservation, tennessee: behavior, knowledge, and risk perception. Sci. Total Environ. 299, 145-161.

Cecelski, D.S., 2001. The Waterman's Song: Slavery and Freedom in Maritime North Carolina. University of North Carolina Press, Chapel Hill, NC.

Centers for Disease Control and Prevention, 2003. Second National Report on Human Exposure to Environmental Chemicals. Atlanta GA: Centers for Disease Control and Prevention. National Center for Environmental Health publication 02-0716.

Centers for Disease Control and Prevention, 2005. Third National Report on Human Exposure to Environmental Chemicals. Atlanta GA: Centers for Disease Control and Prevention. National Center for Environmental Health publication 05-0570.

Chess, C., Burger, J., McDermott, M.H., 2005. Speaking like a state: environmental justice and fish consumption advisories. Soc. Nat. Res. 18, 267-278.

Delaware River Basin Commission. Bioaccumulation of polychlorinated biphenyls in the Delaware River estuary. Available at: 〈http://nj.gov/drbc/ pcb/Jan2004report.htm > accessed on July 2, 2006.

DeNavas-Walt, C., Proctor, B.D., Lee, C.H., 2006. Income, Poverty, and Health Insurance Coverage in the United State. Washington DC: U.S. Census Bureau. Economic and Statistics Administration publication P60-231.

Engle, C.R., 1998. Analysis of regional and national markets for aquacultural food products in the Southern Region. Stoneville MS: Southern Regional Aquaculture Center. SRAS Report 601.

Fensterheim, R.J., 1993. Documenting temporal trends of polychlorinated biphenyls in the environment. Regul. Toxicol. Pharmacol. 18, 181-201.

Finklea, J., Priester, L.E., Creason, J.P., Hauser, T., Hinners, T., Hammer, D.I., 1972. Polychlorinated biphenyl residues in human plasma expose a major urban pollution problem. Am. J. Public Health 62, 645-651.

Food and Drug Administration. Dioxin analysis results/exposure estimates. Available at: 〈http://www.cfsan.fda.gov/ lrd/dioxdata.html〉 accessed May $5,2005$.

Foran, J.A., Carpenter, D.O., Hamilton, M.C., Knuth, B.A., Schwager, S.J., 2005. Riskbased consumption advice for farmed Atlantic and wild Pacific salmon contaminated with dioxins and dioxin-like compounds. Environ. Health Perspect. 113, 552-556.

Gee, G., Payne-Sturges, D.C., 2004. Environmental health disparities: a framework for integrating psychosocial and environmental concepts. Environ. Health Perspect. 112, 1645-1653.

Gibson, J.C., McClafferty, J.A., 2005. Chesapeake Bay angler interviews. Virginia Polytechnic Institute VA: Conservation Management Institute. CMI-HDD-0501.

Gray, K.A., Klebanoff, M.A., Brock, J.W., Zhou, H., Darden, R., Needham, L., Longnecker, M.P., 2005. In utero exposure to background levels of polychlorinated biphenyls and cognitive functioning among school-age children. Am. J. Epidemiol. 162, 17-26.

Hale, R.C., Alaee, M., Manchester-Neesvig, J.B., Stapelton, H.M., Ikonomou, M.G., 2003. Polybrominated diphenyl ether flame retardants in the North American environment. Environ. Int. 29, 771-779.

Harvey, D.J., 2005. Aquaculture Outlook. Washington DC: U.S. Department of Agriculture; Economic Research Service publication LDP-AQS-21.

Hayward, D.G., Nortrup, D., Gardner, A., Clower Jr, M., 1999. Elevated TCDD in chicken eggs and farm-raised catfish fed a diet with ball clay from a Southern United States mine. Environ. Res. 81, 248-256.

Henderson E. 2004. Participation and expenditure patterns of African-American Hispanic, and Women hunters and anglers: Addendum to the 2001 National Survey of fishing, hunting, and wildlife-associated recreation. Report 2001-4. Arlington VA: U.S. Fish and Wildlife Service.

House, J.S., Williams, D.R., 2000. Understanding and reducing socioeconomic and racial/ethnic disparities in health. In: Promoting Health: Intervention 
strategies from social and behavioral research. National Academies Press, Washington DC, pp. 81-124.

House, L., Hanson, T., Sureshwaran, S., Selassie, H., 2003. Opinions of consumers about farm-raised catfish: Results of a 2000-2001 survey. Mississippi State MS: Mississippi Agriculture \& Forestry Experiment Station. MAFES bulletin 1134.

Institute of Medicine, 1991. Seafood safety. Food and Nutrition Board National. Academy of Sciences, Washington, DC.

James, R.A., Hertz-Picciotto, I., Willman, E., Keller, J.A., Charles, M.J., 2002 Determinants of serum polychlorinated biphenyls and organochlorine pesticides measured in women from the child health and development study cohort, 1963-1967. Environ. Health Perspect. 110, 617-624.

Jensen, E., Bolger, P.M., 2001. Exposure assessment of dioxin/furans consumed in dairy foods and fish. Food Addit. Contam. 18, 395-403.

Judd, N., Griffith, W.C., Faustman, E.M., 2004. Contribution of PCB exposure from fish consumption to total dioxin-like dietary exposure. Regul. Toxicol. Pharmacol. 40, 125-135.

Knuth, B.A., Connelly, N.A., Sheeshka, J., Patterson, J., 2003. Weighing health benefit and health risk information when consuming sport-caught fish. Risk Anal. 23 1185-1197.

Krieger, N., Wolff, M.S., Hiatt, R.A., Rivera, M., Vogelman, J., Orentreich, N., 1994 Breast cancer and serum organochlorines: a prospective study among white, black, and Asian women. J. Natl. Cancer Inst. 86 (8), 589-599.

Kutz, F.W., Wood, P.H., Bottimore, D.P., 1991. Organochlorine pesticides and polychlorinated biphenyls in human adipose tissue. Rev. Environ. Contam. Toxicol. 120, 1-82.

Lordo, RA., Dinh, K.T., Schwemberger, J.G., 1996. Semivolatile organic compounds in adipose tissue: estimated averages for the US population and selected subpopulations. Am. J. Public Health 86, 1253-1259.

Lorentz, W., Anniston PCB Site, CSTAG Stakeholders Meeting, June 22, 2005 Available at: <http://www.fws.gov/daphne/Contaminants/Anniston\%20PCB\% 20Site\%20June\%2022\%202005\%20CSTAG\%20Meeting\%20-\%20FINAL.pdf > accessed on November 20, 2006.

Mahaffrey, K.R., Clickner, R.P., Budurow, C.C., 2004. Blood organic mercury and dietary mercury intake: National Health and Nutrition Examination Survey, 1999 and 2000. Environ. Health Perspect. 112, 562-570.

McDermott, M.H., Chess, C., Perez-Lugo, M.L., Pflugh, K.K., Bochenek, E., Burger, J. 2003. Communicating a complex message to the population most at risk: an outreach strategy for fish consumption advisories. Appl. Environ. Educ Commun. 2, 39-48.

Michigan Department of Environmental Quality. 2004. Michigan fish contaminan monitoring program annual report. Available at: 〈http://www.deq.state.mi.us / documents/deq-wb-swas-fcmpreport2004.pdf $>$ accessed on July 2, 2006

National Environmental Justice Advisory Committee, 2002. Fish Consumption and Environmental Justice. NEJAC, Washington, DC.

National Research Council, 1991. Monitoring Human Tissues for Toxic Substances. National Academies Press, Washington, DC.

Pennsylvania Coastal Zone Management Program, 2004. Delaware estuary fish consumption survey. Philadelphia, PA: Philadelphia Department of Environmental Protection.

Recreational boating and fishing foundation, 2002. Minority anglers and boaters: Attitudes and participation in fishing, boating and resource stewardship. Alexandria VA: Recreational boating and fishing foundation; Roper number CNT547.

Robinson, P.E., Mack, G.A., Remmers, J., Levy, R., Mohadjer, L., 1990. Trends of PCB, hexachlorobenzene, and beta-benzene hexachloride levels in the adipose tissue of the U.S. population. Environ. Res. 53 (2), 175-192.

Schecter, A., Papke, O., Harris, T.R., Tung, K.C., Musumba, A., Olson, J., Birnbaum, L. 2006. Polybrominated diphenyl ether (PBDE) levels in an expanded market basket survey of U.S. food and estimated PBDE dietary intake by age and sex. Environ. Health Perspect. 114 (10), 1515-1520.

Schecter, A., Papke, O., Ryan, J.J., Rosen, R., Tung, K.C., Pavuk, M., Staskal, D. Birnbaum, L., Quyhn, H.T., Constable, J.D., 2004a. PBDEs in U.S. milk, blood, and food, and temporal trends for PBDEs, PCDDs, and PCBs in US blood. Organohalogen Cmpd. 66, 2834-2840.

Schecter, A., Papke, O., Tung, K.C., Staskal, D., Birnbaum, L., 2004b. Polybrominated diphenyl ethers contamination of United States food. Environ. Sci. Technol. 38 (20), 5305-5311.

Schlumberger Limited. 2003. Lake Hartwell fish and sediment study. Available at: <http://www.epa.gov/region4/waste/npl/nplsc/sangamoref/ ref\%2002\%202003.pdf > accessed on July 2, 2006.

Staskal, D.F., Ferriby, L.L., Williams, E.S., Luksemburg, W.J., Haws, L.C., Birnbaum, L.S., Paustenbach, D.J., Harris, M.A., 2006. Polybrominated diphenyl ethers in Southern Mississippi Catfish. Organohalogen Cmpd. 68, 1839-1842.

Strauss, H., 2004. Sportsfish consumption surveys: a risk assessment practitioner's wish list. Hum. Ecol. Risk Assess 10, 1213-1225.

Toaspern, M., 2003. Bioaccumulation of Polychlorinated Biphenyls in the Delaware River Estuary. Thesis. University of Maryland, College Park.
Toth Jr, J.F., Brown, R.B., 1997. Racial and gender meanings of why people participate in recreation fishing. Leisure Sci. 19, 129-146.

Toxicology Excellence for Risk Assessment, 1999.Comparative dietary risks: Balancing the risks and benefits of fish consumption. Cincinnati $\mathrm{OH}$ : Toxicology Excellence for Risk Assessment.

US Environmental Protection Agency, 1980. PCB Residue Levels in Human Adipose Tissue; a Statistical Evaluation by Racial Grouping. Washington DC: U.S. Environmental Protection Agency. USEPA publication EPA-560/13-79-015.

US Environmental Protection Agency, 1997. Mercury study report to Congress Volume IV: An assessment of exposure to mercury in the United States. Washington DC: U.S. Environmental Protection Agency; USEPA publication EPA-452/R-97-006.

US Environmental Protection Agency, 1999a. Polychlorinated biphenyls (PCBs) update: Impact on fish advisories. Washington DC: U.S. Environmental Protection Agency; USEPA publication EPA-823-F-99-019.

US Environmental Protection Agency, 1999b. Polychlorinated dibenzo-p-dioxins and related compounds: Impact on fish advisories. Washington DC: U.S. Environmental Protection Agency; USEPA publication EPA-823-F-99-015.

US Environmental Protection Agency, 2002a. National Recommended Water Quality Criteria: 2002. Washington DC: U.S. Environmental Protection Agency. USEPA Publication EPA-822-R-02-047.

US Environmental Protection Agency, 2002b. Field Sampling Plan for the National Study of Chemical Residues in Lake Fish Tissue. Washington DC: U.S. Environmental Protection Agency. USEPA Publication EPA-823-R-02-004.

US Environmental Protection Agency, 2003. EPA's Draft Report on the Environment-Technical Document. Washington DC: U.S. Environmental Protection Agency; US EPA publication EPA 600-R-03-050.

US Environmental Protection Agency, 2004. Technical Memorandum: Origin of 1 meal/week noncommercial fish consumption rate in national advisory for mercury. Washington DC: U.S. Environmental Protection Agency; March 11.

US Environmental Protection Agency, 2005a. Quality Assurance Report for the National Study of Chemical Residues in Lake Fish Tissue: Year 1 through Year 4 Analytical Data. Washington DC: U.S. Environmental Protection Agency; USEPA Publication EPA-823-R-05-005.

US Environmental Protection Agency, 2005b. National listings of fish advisories database. Available at: http://www.epa.gov/waterscience/fish/advisories/index. html $>$ access April 22, 2005.

US Environmental Protection Agency, 2005c, 2004 National listing of fish advisories-fact sheet. Washington DC: U.S. Environmental Protection Agency; USEPA Publication EPA-823-F-05-004.

US Environmental Protection Agency. 2006a. Fish advisories-Where you live. Available at:〈http://epa.gov/waterscience/fish/states.htm〉 accessed July 2 , 2006

US Environmental Protection Agency. 2006b. Locate Your Watershed. Available at: 〈http://cfpub.epa.gov/surf/locate/index.cfm〉 accessed on November 20, 2006.

US Environmental Protection Agency. 2006c. Proposed Indicators for 2007 Report on the Environment-Chapter 2: Contaminants in Lake Fish Tissue. Available at: 〈http://www.epa.gov/ncea/ROEIndicators/pdfs/ContamLakeFishTissue_final. pdf $>$ accessed on September 4, 2006.

US Fish and Wildlife Service. 2006. Fish consumption advisories in the Ashtabula River assessment area. Available at: 〈http://www.fws.gov/midwest/AshtabulaNRDA/documents/AshtabulaFishAdvisoryRpt.pdf $\rangle$ accessed on July 2, 2006.

Van den Berg, M., Birnbaum, L.S., Denison, M., De Vito, M., Farland, W., Feeley, M., Fiedler, H., Hakansson, J., Hanberg, A., Haws, L., Rose, M., Safe, S., Schrenk, D., Tohyama, C., Tritscher, A., Tuomisto, J., Tysklind, M., Walker, N., Peterson, R.E., 2006. The 2005 World Health Organization re-evaluation of human and mammalian toxic equivalency factors for dioxins and dioxin-like compounds. Toxicol. Sci. 93 (2), 223-241.

Veith, G.D., Kuehl, D.W., Leonard, E.N., Puglisi, F.A., Lemke, A.E., 1979. Fish, wildlife, and estuaries-Polychlorinated biphenyls and other organic chemical residues in fish from major watersheds of the United States, 1976. Pestic. Monit. J. 13 (1), $1-11$.

Virginia Department of Environmental Quality. 2003. Fish tissue analysis for PCBs-Available at: <http://www.deq.state.va.us/fishtissue/documents/ 2003 fishpcbs.xls $>$ accessed on July 22006.

Virginia Department of Environmental Quality. 2004. Fish tissue analysis for PCBs-Available at: 〈http://www.deq.state.va.us/fishtissue/documents/ 2004fishpcbs.xls > accessed on July 22006.

Webber, T., 2006. Critics: fish warnings fail to hook those most at risk. The Indianapolis Star. June 7.

West Virginia Department of Health and Human Resources. 2006. West Virginia PCB and Mercury Data Associated with 2006 Fish Consumption Advisories. Available at: 〈http://www.wvdhhr.org/fish/Data/Fish\%20Tissue\%20by\%20Species\% 20for\%20webpage\%202005.pdf $>$ accessed on July 2.

Wisconsin Department of Natural Resources. 2006. Choose Wisely: A Health Guide for Eating Fish in Wisconsin. Madison, WI: Wisconsin Department of Natural Resources; Report \#FH-824-2006. 